\title{
KONFLIK DALAM TATA KELOLA GURU DI SATUAN PENDIDIKAN
}

\section{CONFLICT OF TEACHER MANAGEMENT IN EDUCATIONAL INSTITUTION}

\author{
Prima Dewi, Aceng M. Mirfani,Asep Sudarsyah \\ Universitas Pendidikan Indonesia, Bandung, Indonesia \\ primadewi49@gmail.com
}

\begin{abstract}
ABSTRAK
Penelitian ini bertujuan untuk mendapatkan gambaran mengenai konflik yang terjadi dalam tata kelola guru pada salah satu satuan pendidikan di kabupaten Bandung Barat. Penelitian ini menggunakan pendekatan kualitatif deskriptif. Dalam pengumpulan data peneliti menggunakan teknik observasi, wawancara, dan studi dokumentasi. Adapun Subjek dalam penelitian ini adalah Pengurus yayasan, Kepala Sekolah, dan Guru. Hasil yang di tunjukan dalam penelitian ini adalah: (1) Konflik dalam tata kelola guru pada satuan pendidikan di kab. Bandung Barat ini terjadi dalam konsteks perubahan terhadap sistem manajemen, (2) faktorfaktor yang mempengaruhi terjadinya konflik adalah rasa tertekan yang dialami sebagian besar guru terkait perubahan yang diterapkan dalam waktu yang relatif singkat, dan adanya kebijakan pengurangan masa kerja melalui pembaharuan SK guru. Adapun Implikasi dari penelitian ini adalah, bertambahnya kualitas kerja guru, tingginya kreativitas dan rasa tanggung jawab guru dalam melaksakan tugas dan fungsinya pada salah satu satuan pendidikan di kab. Bandung Barat ini.
\end{abstract}

Kata kunci: konflik, tata kelola guru, dan satuan pendidikan

\section{ABSTRACT}

This research aims to figure out the conflicts that occur in the teacher management in educational institution. This research used descriptive qualitative approach, data collecting using observation techniques, interviews, and study documentation. The Subjects in this research are Foundation Management, Principals, and Teachers. The results shown that: (1) Conflict of teacher management in educational institution occurs in the context of changes to the management system, (2) the factors that affect the occurrence of conflict was a feeling of distress experienced by most teachers regarding the changes implemented in a relatively short time, and the existence of policy reduction through the renewal of teacher decree. The implication of this research was increasing quality of teacher work, the high creativity and sense of responsibility of teachers in performing their duties and functions in one of the educational institution.

Keywords: conflict, teacher management, and educational institution

\section{PENDAHULUAN}

Satuan pendidikan sebagai tempat berlangsungnya proses pembelajaran, penanaman dan pengembangan potensipotensi individu manusia, sehingga diperlukan guru sebagai tenaga pendidik yang profesional. UU RI No 20 tahun 2003 tentang sistem pendidikan nasional, secara eksplisit menyatakan bahwa pendidik merupakan Jurnal Penelitian Pendidikan "tenaga profesional" yang bertugas dalam merencanakan dan melaksanakan proses pembelajaran, melakukan pembimbingan, dan pelatihan, serta melakukan penelitian dan pengabdian kepada masyarakat. Namun, yang terjadi dilapangan, tidak sedikit guruguru yang masih belum sesuai dalam melaksanakan tugas dan kewajibannya sebagai tenaga profesional sehingga perlu 
dilakukan tata kelola terhadap guru.

Pada satuan pendidikan yang didirikan masyarakat, pemerintah menyerahkan sepenuhnya kewenagan untuk merumuskan berbagai kebijakan yang dapat dijadikan sebagai nilai-nilai atau acuan dalam pelaksanaan pendidikan. Akan tetapi tidak sedikit kebijakan - kebijakan yang ditetapkan suatu yayasan menjadi pemicu timbulnya konflik atau oposisi interaktif dalam suatu organisasi.

Sebagaimana yang terjadi pada salah satu satuan pendidikan di kb. Bandug Barat. Adanya perubahan pada sistem manajemen di satuan pendidikan ini menyebabkan timbulnya gesekan atau pertentangan antara guru dengan kepala sekolah dan antar guru dengan pengurus yayasan.

Terjadinya gesekan atau pertentangan pada satuan pendidikan ini disebabkan adanya rasa tertekan yang dialami sebagian besar guru terkait dengan perubahan sistem dalam manajemen pada satuan pendidikan ini. Beberapa kebijakan yang pada awalnya di serahan kepada masig-masing unit, saat ini semua kebijakan di komando yayasan dengan lebih menuntutut guru-guru untuk merubah budaya kerja dan lebih mengedepankan kepentingan yayasan sebagai penyelenggaa pendidikan pada satuan pendidikan ini.

Banyaknya perubahan yang cukup signifikan dalamkebijakanyayasanseperti;(1) Diberlakukannya sangsi berupa pengurangan masa kerja melalui pembaharuan SK, (2) Tidak diperkenankannya guru melakukan aktivitas pribadi (sarapan/sholat duha) disaat jam kerja, dan (3) Diwajibkannya guruguru megikuti kegiatan pelatihan sampai dengan harus menginap di masing-masing unit membuat pertentangan ini menjadi konflik yang harus dihadapi yayasan dalam melakukan tatakelola terhadap guru di satuan pendidkan ini.

\section{KAJIAN TEORI}

1. Konflik

Konflik diartikan sebagai proses pertentangan yang diekspresikan diantara dua pihak atau lebih yang saling tergantung mengenai objek konflik, menggunakan pola perilaku dan interaksi konflik yang mengeluarkan keluaran konflik" (Wirawan 2009:5). Ada dua pengertian tentang konflik yang dijelaskan Thomas dalam Barki \& Hartwick (2001:199), yang pertama adalah tanggapan ketidakcocokan yang ada dalam diri individu, seperti perilaku konflik dimana seseorang harus memilih ya atau tidak dalam melakukan suatu hal atau pertentangan peran dimana ia harus memilih salah satu dari tuntutan penggunaan peran tersebut. Kemudian pengertian konflik yang kedua yaitu konflik yang timbul karena adanya perbedaan individual, kelompok, organisasi, atau unit sosial lainnya.

TosidanMero (2003:189) mengidentifikasi sejumlah faktor pemicu konflik. Faktor-faktor tersebut mereka kelompokkan ke dalam 3 kategori utama yaitu: (1) Perbedaan Karakter Individu; (2) Kondisi Situasional; dan (3) Kondisi Keorganisasian. Konflik bukanlah hal yang harus ditakuti dalam kehidupan, karena konflik apabila di kelola dengan baik akan berdampak besar baik dalam kehidupan umat manusia maupun dalam sebuah organisasi dalam mencapai tujuan dari organisasi. Menurut Wirawan (2009:106) "konflik mempunyai dampak positif dan 
negatif yang dapat menciptakan perubahan bagi kehidupan umat manusia yang akan mengubah kehidupan manusia menjadi lebih baik". Salah satu dampak positif dari suatu konflik adalah terciptanya suatu perubahan. Menurut Wirawan (2009:106) "Konflik dapat menciptakan perubahan dalam kehidupan umat manusia menjadi lebih baik".

\section{Tata Kelola Guru}

Tata kelola adalah suatu perilaku, cara atau metode yang digunakan oleh suatu organisasi untuk mendayagunakan seluruh potensi dan unsur-unsur yang dimiliki secara optimal, dalam upaya mencapai visi dan misi yang telah ditetapkan (Djanali, 2005:8).

Sedangkan Guru adalah orang yang pekerjaannya mengajar (Kamus Besar Bahasa Indonesia, 2001:288). Guru merupakan bagian terpenting yang berperan dalam pemberdayaan peserta didik, guru dapat memiliki kemampuan dan keterampilan khusus dalam bidang mata pelajaran dan pedagogis melalui pelatihan sehingga menghasilkan peserta didik yang berkualitas.

Secara umum tata kelola terkait dengan aspek Transparasi, Akuntabilitas, Kepemimpinan, Komitmen dan sebagainya. Namun, tata kelola menjadi persoalan yang lebih pelik ketika tuntutan tata kelola yang baik mengharuskan adanya perubahan dan inovasi dari sistem yang ada dalam mencapai tujuan organisasi.

Tata kelola merupakan suatu kondisi yang menjamin adanya proses kesejajaran, kesamaan, dan keseimbangan peran, serta adanya saling mengontrol yang dilakukan oleh komponen terkait. Untuk mencapai tata kelola yang baik, diperlukan suatu gerakan perubahan budaya organisasi secara simultan, yaitu gerakan yang mampu mengubah semua kelemaan dan ketidak berdayaan organisasi menjadi lebih handal dan produktif. Dengan demikian, dapat dipahami bahwa dalam melaksanakan tatakelola yang baik, adakalanya diperlukan reorganisasi dan pemberdayaan disemua lini organisasi guna mencapai kesuksesan organisasi sebagai mana dicita-citakan (Djanali, 2005:10).

\section{Satuan Pendidikan}

Satuan pendidikan atau Sekolah memiliki fungsi mendasar yaitu sebagai tempat berlangsungnya proses pembelajaran, penanaman dan pengembangan potensipotensi individu manusia, sehingga membentuk Insan/ Manusia yang mulia. Satuan Pendidikan juga disebut sebagai suatu sistem organisasi yakni suatu kesatuan sosial dari sekelompok manusia yang berinteraksi menurut suatu pola tertentu sehingga setiap anggota organisasi memiliki fungsi dan tugasnya masing-masing.

Sekolah adalah lembaga yang bersifat "kompleks dan unik", Dimana terdapat dimensi yang saling berkaitan satu sama lain, dan memiliki ciri-ciri tertentu yang tidak dimiliki oleh organisasi-organisasi lain, seperti tempat terjadinya proses pembelajaran dan pembudayaan kehidupan manusia Wahjosumidjo (2011:81). Secara garis besarsoebagio (2000:65) menuturkan fungsi sekolah sebagai berikut:

1. Mendidik calon warga negara yang dewasa.

2. Mempersiapkan calon warga masyarakat.

3. Mengembangkan cita-cita profesi atau kerja. 
4. Mempersiapkan calon pembentuk keluarga yang baru.

5. Pengembangan diri (realisasi pribadi).

Sebagai satuan pendidikan sekolah juga memiliki tanggung jawab yang besar terhadap perkembangan perserta didik dan peningkatan mutu pendidikan di sekolah dengan mendayagunakan komponenkomponen sekolah secara maksimal dalam kehidupan yang bersifat nyata disekitarnya (Daryanto, 1997:544).

\section{METODE PENELITIAN}

Penelitian ini menggunakan pendekatan kualitatif dengan rancangan studi kasus. Menurut Arikunto (2010: 115) rancangan studi kasus merupakan suatu strategi penelitian yang mengkaji secara intensif, rinci dan mendalam terhadap sebuah organisasi, lembaga atau gejela tertentu. Studi kasus merupakan sarana utama bagi penelitian emik, yakni dengan menyajikan pandangan subyek yang diteliti sehingga dapat ditemukan konsistensi internal yang tidak hanya merupakan konsistensi gaya dan konsistensi faktual tetapi juga keterpercayaan (trustworthtiness).

Lokasi Penelitian ini bertempat di salah satu Satuan Pendidikan (tidak berkenan disebutkan namanya) di Kab. Bandung Barat. Pengumpulan data dalam penelitian ini dilakukan dengan tiga teknik, yaitu wawancara mendalam, observasi partisipan, dan studi dokumentasi. Analisis data dilakukan melalui kegiatan menelaah data, menata, membagi menjadi satuan-satuan yang dapat dikelola, mensintesis, mencari pola, menemukan apa yang bermakna, dan apa yang akan diteliti dan diputuskan peneliti untuk dilaporkan secara sistematis.

Dalam penelitian ini, pemeriksaan keabsahan data didasarkan pada kriteriakriteria untuk menjamin kepercayaan data yang diperoleh melalui penelitian. Dari empat metode pengecekan keabsahan temuan, peneliti hanya menggunakan 3 metode dalam penelitian ini yaitu uji kredibilitas, Dependebilitas (kebergantungan), dan Konfirmabilitas (kepastian).

\section{HASIL DAN PEMBAHASAN}

1. Konteks Konflik

Konflik yang terjadi dalam tata kelola guru pada salah satu satuan pendidikan di kab. Bandung Barat ini adalah dalam konteks perubahan manajemen, adanya peralihan kewenangan yang di putuskan yayasan dengan maksud untuk mempertegas berbagai kebijakan pada satuan pendidika ini tidak disambut hangat oleh guru-guru, hal ini kerena tidak dilakukannya sosialisasi terlebih dahulu sehinga terkesan menekan guru dan memaksa guru untuk keluar dari zona nyaman.

Beberapa kewenangan yang diambil alih yayasan diantaranya adalah kebijakan tentang sistem penilaian dan pengawasan guru, dimana sebelumnya penilaian dan pengawasan terhadap guru adalah tugas kepala sekolah. Penilaian dan pengawasan yayasan terhadap guru menjadi penyebab timbulnya konflik dalm tata kelola guru. Hal ini dikarenakan adanya perubahan standar dari penilaian dan pengawasan yang dilakukan yayasan, dimana yayasan lebih condong menjadikan "Loyalitas" sebagai standar penilaiannya. Keadaan yang demikian ini mengubah pola dan budaya kerja guru yang 
selama ini menjadikan 4 kompetensi dasar sebagai acuan penilaianya.

Menurut Wirawan (2009:106) "Konflik dapat menciptakan perubahan dalam kehidupan umat manusia menjadi lebih baik". Guru sebagai tenaga profesional telah mendapatkan pengakuan secara hukum di Indonesia. Pemahaman Guru sebagai tenaga profesional selanjutnya dipertegas dalam UU RI no 14 tahun 2005 tentang guru dan dosen pada pasal 1 ayat 1 yakni, "guru adalah pendidik profesional dengan tugas utama mendidik, mengajar, membimbing, ... " (balitbang-Diknas,2005).

Merujuk pada kedua undang-undang tersebut, Usman (2006:14-15) dalam bukunya yang berjudul Menjadi Guru Profesional menyatakan; Guru profesional adalah orang yang mempunyai kemampuan dan keahlian khusus dalam bidang keguruan sehingga ia mampu melakukan tugas dan fungsinya sebagai guru dengan kemampuan maksimal. Atau dengan kata lain, guru profesional adalah orang yang terdidik dan terlatih dengan baik, serta memiliki pengalaman yang kaya di bidangnya.

Dari pembahasan tersebut jelas bahwa penilaian terhadap guru lebih di tekankan pada kompetensi diri dan bukan pada tingkat kepatuhan terhadap pimpinan atau biasa disebut loyalitas kepeda yayasan. Meski secara umum tata kelola terkait dengan Kepemimpinan, Komitmen dan sebagainya. Namun, Sekolah adalah lembaga yang bersifat "kompleks dan unik", Dimana terdapat dimensi yang saling berkaitan satu sama lain, dan memiliki ciri-ciri tertentu yang tidak dimiliki oleh organisasi-organisasi lain, seperti tempat terjadinya proses pembelajaran dan pembudayaan kehidupan manusia Wahjosumidjo (2011:81). Sehingga fungsi sekolah sebagai mana telah digaris besarkan, soebagio (2000:65) dapat tercapai sepenuhnya.

\section{Faktor-faktor Yang Mempengaruhi}

\section{Konflik}

Faktor-faktor yang mempengaruhi terjadinya konflik pada satuan pendidikan ini adalah adanya kebijakan atau aturan yang dipandang merugikan guru. Kebijakan atau aturan yang dimaksud disini adalah adanya sangsi bagi berupa pengurangan masa kerja melalui pebaharuan SK guru. Hal ini membuat ketegangan dikalangan guru semakin bergejolak karena SK guru memiliki pengaruh yang cukup besar dalam keperluan administatif guru. Terlebih dengan sikap kepala sekolah yang lebih mencari aman, seolah tidak ingin terlibat dalam permasalahan yang sedang dihadapi guru, membuat beberapa guru lebih memilih untuk mengundurkan diri sebagai tenaga pendidik di satuan pendidikan ini.

Sebagai satuan pendidikan sekolah juga memiliki tanggung jawab yang besar terhadap perkembangan perserta didik dan peningkatan mutu pendidikan di sekolah dengan mendayagunakan komponenkomponen sekolah secara maksimal dalam kehidupan yang bersifat nyata disekitarnya (Daryanto, 1997:544).

Perubahan dalam dunia pendidikan mencakup dua komponen utama perubahan yang saling terkait, satunya adalah perubahan dalam pengelolaan, dimana di dalamnya juga mencakup berbagai kebijakan yang telah ditetapkan. Karena organisasi pendidikan 
dilihat sebagai satu keutuhan yang harus senantiasa diupayakan untuk meningkatkan output pendidikan. Maka perubahan dalam pengelolaan ini menuntut adanya pemimpin yang memiliki kemampuan dan kesiapan untuk mempengaruhi, mendorong, mengajak, menuntun, menggerakan, mengarahkan, dan bila perlu memaksa orang atau kelompok guru agar menerima pengaruh yang datang dari perubahan tersebut dan bukan pemimpin yang memiliki sikap yang cenderung lebih mencari aman dan enggan melibatkan diri dalam permasalahan yang dihadapi guru. Selain itu, seorang pemimpin / kepala sekolah juga di tuntut untuk dapat melakukan sesuatu sebagai upaya membantu tercapainya tujuan tertentu dari perubahan yang telah ditetapkan (Wibowo, 2006:9).

\section{SIMPULAN DAN SARAN}

Dari pembahasan di atas, dapat disimpulkan bahwa konflik yang terjadi dalam tata kelola guru di satuan pendidikan ini adalah dalam konteks perubahan manajemen yang menjakup pada peralihan kewenangan dan perubahan standar penilaian terhadap guru. Hal yang mempengaruhi semakin bergejolaknya konflik yang terjadi adalah adanya kebijakan terkait dengan sanksi berupa pengurangan masa kerja melalui pembaharuan SK guru. Keadaan yang demikian ini mengakibatkan sebagian besar guru mengundurkan diri dari satuan pendidikan di kab. Bandung Barat ini. Hal ini jika dibiarkan tentu akan mempengaruhi pada fungsi dan tanggung jawab sekolah sebagai satuan pendidikan.

Untuk menjaga kestabilan organisasi, yayasan perlu membentuk tim yang betulbetul memahami strategi untuk menerapkan perubahan dalam manajemen yang ada saat ini. Memberikan memotivasi terhadap guru dengan sebuah pengakuan sebagai bentuk penghargaan. Pemimpin di setiap unit diharapkan mampu menyikapi konflik yang terjadi, agar komunikasi dengan guru dapat selalu terjaga dengan baik. Dan mengagendakan berbagi kegiatan pelatihan, pembinaan, dan evaluasi guru untuk meningkatkan kompetensi guru.

\section{DAFTAR RUJUKAN}

Arikunto. (2010).Prosedur penelitian: Suatu pendekatan Praktek, edisi revisi. Jakarta: Rineka Cipta.

Barki, H.,\& Hartwick, J. (2001) Interpersonal Conflict and its Management in Information System Management. MIS Quarterly. Vol 25, No 2.

Daryanto. (1997).Evaluasi Pendidikan. Jakarta: Rineka Cipta.

Tosi, H. L., \&Mero, N. P. (2003) The Fundamentals of Organizational Behavior: What Managers Need to Know. Massachussetts: Blacwell Publishing, p.189-91.

Pusat Bahasa Departemen Pendidikan Nasional. (2001).Kamus Besar Bahasa Indonesia, Jakarta: Balai Pustaka. Edisi III.

Soebagio, A. (2000).Manajemen Pendidikan Indonesia, Jakarta: PT Ardadizya Jaya.

Djanali, S. (2005).Buku X - Tata Kelola. Jakarta: Direktorat Pembinaan Akademik dan Kemahasiswaan, Direktorat Jendral Pendidikan Tinggi - Depdiknas.

Undang - Undang RI, Nomor 14, tahun 2005, Pasal 8, Tentang Guru dan Dosen. 
Usman, M. U. (2006).Menjadi guru Profesional. Bandung: PT. Remaja Rosda Karya.

Wahjosumidjo. (2011). Kepemimpinan Kepala Sekolah Tinjauan Teoritik dan Permasalahannya. Jakarta: Raja Grafindo Persada.

Wibowo. (2006). Managing Change Pengantar Manajemen Perubahan. Bandung: AlfaBeta.

Wirawan. (2009). Konflik dan Manajemen Konflik. Jakarta: Salemba Humanika. 